\title{
PERAN GAYA KEPEMIMPINAN KEPALA SEKOLAH DALAM MENINGKATKAN KINERJA GURU DAN MUTU SEKOLAH (STUDI KASUS DI SD NEGERI 02 BATIPUH KECAMATAN BATIPUH SELATAN)
}

\author{
Osreni \\ Guru SD Kecamatan Batipuh Kab. Tanah Datar, Sumatera Barat \\ e-mail: osreni0307@gmail.com
}

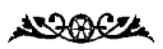

\begin{abstract}
The purpose of the study was to describe the role of principal leadership style in improving teacher performance and school quality in SD Negeri 02 Batipub, Batipub Selatan District. This research belongs to field research category. This research uses qualitative research approach. Sources of data in this study is seen from the primacy of the object to obtain more objective information. The data source is divided into two parts, the primary data source, the principal at the school. Secondary data sources are as supporting data related to this research, that is teachers, administration and students and school committee. Data collection is done through observation, interview and documentation study. The analyst technique used is as follows: (1) data collection, (2) data reduction, (3) data display, and (4) conclusion The results show that, Head of SD Negeri 02 Batipuh has multi leadership style in lead Schools, this is done depending on the situation and conditions in the field. In improving the performance of teachers and the quality of schools, principals of SD Negeri 02 Batipuh apply various strategies, and it can be realized.There is a significant result in SD Negeri 02 Batipub during led by head the current school.
\end{abstract}

Keywords: Leadership Style, Headmaster, Teacher Performance, School Quality

\section{PENDAHULUAN}

Sekolah sebagai sebuah organisasi yang dipimpin oleh kepala sekolah. Di negara maju, kepala sekolah mendapat sebutan bermacam-macam. Ada yang menyebut guru kepala (head teacher atau head master), kepala sekolah (principal), kepala sekolah yang mengajar (teaching principal), direktur (directur), administrator, pemimpin pendidikan (educational leadership). Sebagai pemimpin pendidikan yang professional, kepala sekolah dituntut untuk selalu mengadakan perubahan, mereka harus memiliki semangat yang berkesinambungan untuk mencari terobosan-terobosan baru demi menghasilkan suatu perubahan yang bersifat pengembangan dan penyempurnaan.dari kondisi yang memprihatinkan menjadi kondisi yang lebih dinamis, baik segi fisik maupun akademik, seperti perubahan semangat keilmuan, atmosfer belajar dan peningkatan strategi pembelajaran. Disamping itu, Kepala sekolah juga harus 
berusaha keras menggerakkan para bawahannya untuk berubah, setidaknya mendukung perubahan yang dirintis kepala sekolah secara proaktif, dinamis, bahkan progresif, sistem kerja para bawahan harus lebih kondusif, kinerja mereka harus dirangsang supaya meningkat, disiplin mereka harus dibangkitkan, sikap kerjasama mereka lebih dibudayakan, dan suasana harmonis diantara mereka lebih diciptakan.

Pentingnya pemimpin dan kepemimpinan ini perlu dipahami dan dihayati oleh setiap umat Islam di negeri yang mayoritas warganya beragama Islam ini, meskipun Indonesia bukanlah negara Islam. Allah telah berfirman kepada manusia, tentang pentingnya kepemimpinan dalam Islam, sebagaimana tertulis dalam al-Qur'an Surat Al-baqarah ayat 30 yaitu: "Ingatlah ketika Tubanmu berfirman kepada Para Malaikat: "Sesungguhnya aku hendak menjadikan seorang khalifah di muka bumi." mereka berkata: "Mengapa Engkau bendake menjadikan (khalifah) di bumi itu orang yang akan membuat kerusakan padanya dan menumpabkan darah, Padabal Kami Senantiasa bertasbih dengan memuji Engkau dan mensucikan Engkau?" Tuhan berfirman: "Sesunggubnya aku mengetahui apa yang tidak kamu ketahui." (QS. Al-baqarah: 30). Ayat ini mengisyaratkan bahwa khalifah (pemimpin) adalah pemegang mandat Allah SWT untuk mengemban amanah dan kepemimpinan langit di muka bumi. komunitas malaikat pernah memprotes terhadap kekhalifahan manusia di muka bumi.

Masalah kinerja bagi para guru adalah masalah yang sangat penting. Tanpa adanya kinerja yang baik tidak mungkin sekolah dapat menghasilkan peserta didik yang kompetitif. Peningkatan kinerja mempunyai implikasi yang positif bagi sekolah itu sendiri, artinya sekolah dapat menghasilkan kuantitas dan kualitas peserta didik yang optimal. Kinerja guru akan meningkat bila didukung oleh penerapan sistem manajemen kinerja dan sistem pengembangan karir yang baik dan efektif serta penerapan kerja tim dan partisipasi guru di sekolah, bila sistem menajemen kerja sudah meningkat secara otomatis mutu pendidikan di sekolah tersebut juga akan meningkat.

Salah satu faktor yang menyebabkan meningkatnya mutu pendidikan adalah guru. Membicarakan proses pendidikan berarti harus membicarakan guru dan kepala sekolah. Merekalah yang melakukan kegiatan proses pembelajaran di sebuah sekolah. Bagaimanapun baiknya masukan (input), sarana, birokrasi, tetapi kalau proses tidak berjalan dengan baik maka mutu pendidikan sulit diharapkan akan meningkat.

Guru merupakan komponen pendidikan yang paling dominan mempengaruhi jalannya proses pendidikan. Hal ini disebabkan karena gurulah yang melaksanakan proses pendidikan serta mengorganisasikan komponen-komponen pendidikan lainnya. Tanpa kehadiran guru proses pendidikan tidak akan berjalan dengan baik, karena posisinya tidak dapat digantikan oleh alat-alat lainnya. Untuk memiliki kinerja yang baik, guru hendaknya memiliki beberapa kompetensi yang akan digunakan dalam melaksanakan tugasnya sebagai seorang pendidik. Berdasarkan Peraturan Menteri Pendidikan Nasional Republik Indonesia Nomor 16 Tahun 2007 tentang Standar Kualifikasi Akademik dan 
Kompetensi Guru dijelaskan bahwa standar kompetensi guru dikembangkan secara utuh dari 4 kompetensi utama, yaitu: (1) kompetensi pedagogik, (2) kepribadian, (3) sosial, dan (4) profesional. Keempat kompetensi tersebut terintegrasi dalam kinerja guru.

Berkaitan dengan masalah peningkatan mutu, peranan kepala SD Negeri 02 Batipuh besar sekali pengaruhnya terhadap keberhasilan pelaksanaan proses pembelajaran dengan cara meningkatkan kinerja guru dan mutu sekolah. Sebagai kepala sekolah, hal tersebut merupakan tantangan pertama dalam menumbuhkan kualitas guru sehingga terwujudnya mutu sekolah yang baik di SD Negeri 02 Batipuh. Menurut salah satu guru kelas, mereka mengatakan, "Semua guru diharapkan untuk melaporkan kinerjanya setiap hari baik secara lisan ataupun tulisan. Hal ini adalah merupakan salah satu kebijakan kepala sekolah di SD Negeri 02 Batipuh hal ini dilakukan guna untuk meningkatkan kinerja guru dan mutu sekolah. Beliau juga menambahkan “ bahwasanya kepala sekolah memiliki multi gaya ketika memimpin, hal ini dilakukan karena latar belakang guru yang berbedabeda".

Menurut guru mata pelajaran Olah Raga, "Kepala sekolah mempunyai kharismatik dalam memimpin, sehingga membuat guru dan staf tata usaha dapat mengajar dan bekerja dengan baik, tanpa ada paksaan dalam memerintah kepada bawahannya. Pada akhirnya rasa segan akan muncul dalam diri guru dan staf tata usaha untuk mengajar dan bekerja sebaik mungkin, sehingga prestasi sekolah ini meningkat terus-menerus dari rangking 12 pada tahun 2012 sampai memperoleh rangking 3 pada tahun 2016, kerja sama antara guru meningkat, guru termotivasi untuk naik pangkat, dan juga kepala sekolah mencari solusi terhadap permasalahan yang dialami oleh guru.

Menurut guru kelas VI, "Dalam memimpin sekolah, kepala SD Negeri 02 Batipuh sangat tegas dalam menerapkan disiplin untuk meningkatkan mutu pendidikan, kepala sekolah akan memberikan reward kepada guru dan siswa yang berprestasi dan memberikan punishment kepada guru dan siswa yang melanggar peraturan yang ada, kepala sekolah melakukannya dengan adil dan bijaksana, hal ini sangat berbeda dengan sebagian kepala sekolah lainnya yang ada di Kecamatan Batipuh Selatan.

\section{LANDASAN TEORI}

\section{Kepemimpinan}

Pengertian umum kepemimpinan adalah kemampuan dan kesiapan yang dimiliki seseorang untuk dapat mempengaruhi, mendorong, mengajak, menuntun, menggerakkan dan kalau perlu memaksa orang lain agar ia menerima pengaruh itu selanjutnya berbuat sesuatu yang dapat membantu pencapaian suatu maksud atau tujuan tertentu (Soetopo: 1988, p.1)

Ada banyak pendapat yang mengemukakan tentang pengertian kepemimpinan, diantaranya adalah telah didefinisikan oleh Robin dalam $T$. (Handoko: 1997, p.8), bahwa kepemimpinan adalah kemampuan untuk mempengaruhi suatu kelompok ke arah 
pencapaian tujuan. Menurut J.M. Pfiffner dalam Sudarwan Danim, bahwa kepemimpinan adalah seni mengokordinasi dan memberi arah kepada individu atau kelompok untuk mencapai tujuan yang diinginkan (Danim: 2008, p.204).

Pada saat suatu proses kepemimpinan berlangsung, seorang pemimpin mengaplikasikan suatu gaya kepemimpinan tertentu. Gaya kepemimpinan yang efektif merupakan gaya kepemimpinan yang dapat mempengaruhi, mendorong, mengarahkan dan menggerakkan orangorang yang dipimpin sesuai dengan situasi dan kondisi supaya mereka mau bekerja dengan penuh semangat dalam mencapai tujuan organisasi. Hersey dan Blanchard menjelaskan bahwa gaya kepala sekolah yang efektif ada empat: (1) gaya instruktif, penerapannya pada bawahan (guru) yang masih baru atau bertugas. (2) gaya konsultatif, penerapannya pada bawahan (guru) yang memiliki kemampuan tinggi namun kemauan rendah, (3) gaya partisipatif, penerapannya pada bawahan (guru) yang memiliki kemampuan rendah, namun memiliki kemauan kerja tinggi, (4) gaya delegatif, penerapannya bagi bawahan (guru) yang memiliki kemampuan tinggi dan kemauan tinggi (Hersey, Blanchard and Kenneth: 1982, p.135).

\section{Kepala Sekolah}

Secara etimologi menurut kamus besar bahasa Indonesia, Kepala Sekolah adalah orang atau guru yang memimpin suatu Sekolah. Dengan demikian Kepala Sekolah merupakan pihak yang ditunjuk untuk memimpin suatu lembaga pendidikan. Sedangkan secara terminologi, Wahjosumidjo mengemukakan pengertian Kepala Sekolah adalah sebagai seorang tenaga profesional guru yang diberi tugas untuk memimpin suatu sekolah di mana diselenggarakan proses belajar mengajar "atau" tempat dimana terjadi interaksi antara guru yang memberi pelajaran dan murid yang menerima pelajaran (Wahjosumidjo: 1999, p.83).

Definisi lain tentang pengertian Kepala Sekolah dikemukakan pula dalam buku kendali mutu pendidikan agama Islam, yang menyatakan bahwa Kepala Sekolah adalah: "orang yang bertugas sebagai pemegang polisi umum dalam menentukan kebijakan di lingkungan Sekolah". Disamping sebagai seorang pemimpin Kepala Sekolah juga merupakan seorang bawahan yang harus mempertanggung jawabkan hasil yang dipimpinya kepada orang atau lembaga yang menunjuknya. Hal ini sabagaimana yang ditegaskan oleh $\mathrm{M}$. Ngalim Purwanto bahwa Kepala Sekolah adalah seseorang yang bertanggung jawab kepada atasannya terhadap tugas yang telah dipikulkan kepadanya pada lingkungan lembaga pendidikan” (Purwanto: 1991, p.62).

Wahjosumidjo mengungkapkan bahwa seorang pemimpin atau Kepala Sekolah dituntut untuk (Wahjosumidjo: 1999, p.115):

a. Bertanggung jawab agar guru, staf dan siswa menyadari akan tujuan sekolah yang telah ditetapkan, dengan kesadaran tersebut para guru, staf dan siswa dengan penuh semangat, keyakinan melaksanakan tugas masing-masing dalam mencapai tujuan sekolah. 
b. Agar guru, staf dan siswa melaksanakan tugas-tugas dengan penuh kesadaran, maka Kepala Sekolah bertanggung jawab untuk menyediakan segala dukungan, peralatan, fasilitas, berbagai peraturan dan suasana yang mendukung kegiatan.

c. Kepala Sekolah harus pula mampu memahami motivasi setiap guru, staf dan siswa, mengapa bersikap dan berprilaku baik yang bersifat positif maupun reaksi yang tidak mendukung.

d. Kepala Sekolah harus tampak sebagai sosok yang selalu dihargai, terpercaya, diteladani, dituruti segala perintahnya, sehingga Kepala Sekolah sebagai seorang pemimpin betul-betul berfungsi sebagai sumber inspirasi bawahan.

e. Kepala Sekolah harus dapat memelihara keseimbangan antara guru, staf, dan siswa di satu pihak dan kepentingan sekolah serta kepentingan masyarakat dipaihak lain. Sehingga tercipta suasana keseimbangan, keserasian antara kehidupan sekolah dengan masyarakat(equalibrun).

f. Tiap kepala sekoalh harus menyadari bahwa esensi kepemimpinan adalah kepengikutan (the followership). Artinya kepemimpinan tidak akan terjadi apabila tidak didukung oleh pengikut atau bawahan. Bawahan dalam hal ini adalah guru, staf dan siswa.

g. Memberikan bimbingan, mengadakan koordinasi kegiatan, mengadakan pengendalian/pengawasan dan mengadakan pembinaan agar masingmasing anggota /bawahan memperoleh tugas yang wajar dalam beban dan hasil usaha bersama.

\section{Kinerja Guru}

Menurut Tabrani Rusyan, kinerja guru adalah melaksanakan proses pembelajaran baik dilakukan di dalam kelas maupun di luar kelas, di samping mengerjakan kegiatan-kegiatan lainnya (Tabrani Rusyan, dkk: 2000, p.17). Dari penjelasan tentang pengertian kinerja secara umum dan kinerja guru secara khusus di atas dapat disimpulkan bahwa kinerja guru adalah kemampuan yang ditunjukkan oleh guru dalam melaksanakan tugas atau pekerjaannya baik yang dilakukan di dalam kelas maupun di luar kelas. Kinerja dikatakan baik dan memuaskan apabila tujuan yang dicapai sesuai dengan standar yang telah ditetapkan.

Kinerja guru mempunyai spesifikasi tertentu. Kinerja guru dapat dilihat dan diukur berdasarkan spesifikasi/kriteria kompetensi yang harus dimiliki oleh setiap guru. Berkaitan dengan kinerja guru, wujud perilaku yang dimaksud adalah kegiatan guru dalam proses pembelajaran yaitu bagaimana seorang guru merencanakan pembelajaran, melaksanakan kegiatan pembelajaran, dan menilai hasil belajar. Selajutnya Simamora menambahkan bahwa ada beberapa persyaratan untuk melihat ukuran kinerja yaitu: (1) relevan dengan individu dan organisasi, (2) stabil dan dapat diandalkan, (3) dapat membedakan antara pekerjaan yang baik dan yang tidak baik, (4) dinyatakan dengan angka, (5) mudah diukur, dan (6) mudah dipahami (Simamora: 1995, p.45).

Kinerja seorang guru perlu dilakukan penilaian untuk mengevaluasi pelaksanaan proses pembelajaran yang telah berlangsung. Untuk menilai kinerja seorang guru 
yang dapat mengambarkan tentang kualitas kinerja seorang guru. Menilai kualitas kinerja dapat ditinjau dari beberapa indikator yang meliputi : (1) unjuk kerja, (2) penguasaan Materi, (3) Penguasaan profesional keguruan dan pendidikan, (4) Penguasaan cara-cara penyesuaian diri, (5). Kepribadian untuk melaksanakan tugasnya dengan baik (Simamora: 1995, p.62).

Sementara Gomez mengemukakan unsur yang berkaitan dengan kinerja terdiri dari Gomez: 2001, p.142):

1. Quantity of work, yakni jumlah pekerjaan yang dapat diselesaikan pada periode tertentu.

2. Quality of work, yaitu kualitas pekerjaan yang dicapai berdasarkan syarat yang ditentukan.

3. Job knowledge, yakni pemahaman pegawai pada prosedur kerjadan informasi teknis tentang pekerjaan.

4. Creativeness, yaitu kemampuan menyesuaikan diri dengan kondisi dan dapat diandalkan dalam pekerjaan.

5. Cooperation, yaitu kerjasama dengan rekan kerja dan atasan.

6. Dependability, yakni kemampuan menyelesaikan pekerjaan tanpa tergantung kepada orang lain.

7. Inisiative, yakni kemampuan melahirkan ide-ide dalam pekerjaan.

8. Personal qualities, yaitu kemampuan dalam berbagai bidang pekerjaan

Menurut Darmodiharjo, ada 3 macam tugas pokok guru yaitu (Darmodiharjo: 1982, p.45):

1. Tugas professional yaitu yang berkenaan dengan profesinya. Tugas ini mencakup tugas mendidik (mengembangkan kepribadian siswa), mengajar (mengem- bangkan kemampuan intelektual), melatih (mengembangkan ketrampilan siswa).

2. Tugas manusiawi (buman respon sibility) yaitu tugas sebagai manusia dalam hal ini guru bertugas mewujudkan dirinya dalam arti merealisasikan seluruh potensi yang dimilikinya, melakukan auto-identifikasi dan pengertian untuk menenpatkan dirinya di dalam keseluruhan kemanusiaan sesuai dengan martabat masing-masing.

3. Tugas kemasyrakatan (civil-mission) yaitu tugas sebagai angota masyarakat dan warga negara, dalam hal ini guru bertugas membimbing siswa menjadi warga negara yang baik sesuai dengan kaidah yang terdapat di dalam pancasila, UUD 1945 dan GBHN sebagai perancang masa depan dan pengerak kemajuan.

\section{Mutu Sekolah}

Menurut Oemar Hamalik, Pengertian mutu dapat dilihat dari dua sisi, yaitu segi normatif dan segi deskriptif. Dalam artian normatif, mutu ditentukan berdasarkan pertimbangan (kriteria) intrinsik dan ekstrinsik. Berdasarkan kritria intrisik, mutu pendidikan merupakan produk pendidikan yakni manusia yang terdidik sesuai dengan standar ideal. Berdasarkan kriteria ekstrinsik, pendidikan merupakan instrumen untuk mendidik, tenaga kerja yang terlatih. Dalam artian deskriptif, mutu ditentukan berdasarkan keadaan hasil tes prestasi belajar (Hamalik: 1990, p.33). Korelasi mutu secara umum dengan mutu sekolah, sebagaimana pengertian yang dikemukakan oleh Dzaujak, mutu sekolah 
adalah kemampuan sekolah dalam pengelolaan secara operasional dan efisien tehadap komponen-komponen yang berkaitan dengan sekolah sehingga menghasilkan nilai tambah terhadap komponen tersebut menurut norma/standar yang berlaku. (Dzaujak: 1996, p.8).

Dari penjelasan diatas dapat disimpulkan bahwa bicara mutu sekolah bukanlah upaya sederhana, melainkan suatu kegiatan dinamis dan penuh tantangan. Mutu sekolah selalu berubah seiring dengan perubahan jaman. Oleh karena itu pendidikan di sekolah senantiasa memerlukan upaya perbaikan dan peningkatan mutu sejalan dengan semakin tingginya kebutuhan dan tuntunan kehidupan masyarakat.

Manajemen peningkatan mutu pendidikan di sekolah adalah suatu metode peningkatan mutu yang bertumpu pada pendidikan di sekolah itu sendiri, mengaplikasikan sekumpulan teknik, mendasarkan pada ketersediaan data kuantitatif \& kualitatif, dan pemberdayaan semua komponen sekolah untuk secara berkesinambungan meningkatkan kapasitas dan kemampuan organisasi sekolah guna memenuhi kebutuhan peserta didik dan masyarakat. Dalam Peningkatan Mutu yang selanjutnya disingkat MPM, terkandung upaya a) mengendalikan proses yang berlangsung di sekolah baik kurikuler maupun administrasi, b) melibatkan proses diagnose dan proses tindakan untuk menindak lanjuti diagnose, c) memerlukan partisipasi semua fihak: Kepala sekolah, guru, staf administrasi, siswa, orang tua dan pakar.

\section{METODE PENELITIAN}

Penelitian ini termasuk dalam kategori penelitian lapangan (field research). Penelitian ini menggunakan pendekatan penelitian kualitatif, yaitu jenis penelitian yang menghasilkan penemuan-penemuan yang tidak dapat diperoleh dengan menggunakan prosedur-prosedur statistik atau dengan cara kuantifikasi lainnya. Melalui penelitian kualitatif peneliti dapat mengenali subjek dan merasakan apa yang mereka alami dalam kehidupan sehari-hari. Menurut definisi ini penelitian kualitatif menghasilkan data deskriptif sehingga merupakan rinci dari suatu fenomena yang diteliti.

Karakteristik sumber data pada penelitian ini adalah dilihat dari keutamaan objek untuk memperoleh informasi yang lebih objektif. Sumber data dibagi kepada dua bagian, yaitu sumber data primer, yaitu kepala sekolah pada sekolah tersebut. Sumber data sekunder adalah sebagai data pendukung yang terkait dengan penelitian ini, yaitu para guru, tata usaha dan siswa dan komite sekolah yang peneliti anggap berhubungan dengan kepemimpinan kepala sekolah dalam meningkatkan kinerja guru dan mutu sekolah. Analisis data adalah upaya peneliti untuk memahami apa yang terdapat dibalik data dan menjadikan suatu informasi yang utuh mudah dimengerti serta menemukan pola umum yang timbul dari data tersebut. Analisis data dapat dilakukan dengan dua metode, yaitu kuantitaf dan kualitatif.

Data yang telah dikumpulkan, dianalisis secara deskriptif kualitatif. Jelasnya, data yang terkumpul dianalisa setiap waktu secara induktif selama 
penelitian berlangsung dengan mengolah bahan empirik, supaya dapat disederhanakan ke dalam bentuk yang lebih mudah dibaca, dipahami, dan diinterpretasikan. Data diinterpretasi untuk mencari makna dan implikasi hubungan yang ada. Analisis induktif dimulai dengan merumuskan terlebih dahulu sejumlah permasalahan ke dalam beberapa pertanyaan yang dijadikan tujuan penelitian. Beberapa pertanyaan yang menjadi permasalahan utama telah dikemukakan dalam perumusan masalah, tetapi pertanyaan-pertanyaan yang lain dapat digali melalui wawancara atau observasi langsung ke lokasi penelitian, sehingga dapat mengumpulkan ungkapan kognitif, emosional atau intuisi dari para pelaku yang terlibat. Data ini dirangkum secara deskriptif untuk membantu menemukan konsep-konsep keaslian yang diungkapkan oleh subjek penelitian sendiri sesuai dengan kenyataan. Dengan cara ini tetap akan dapat menyajikan realitas senyatanya (emik) sebagaimana yang diharapkan dalam penelitian kualitatif. Dalam penelitian data kualitatif salah satu modelnya adalah Model Miles dan Huberman, yaitu analisis data kualitatif dilakukan secara interaktif dan berlangsung secara terus-menerus dari mulai pengumpulan data di lapangan sampai selesai, tuntas dan jenuh. Langkahnya dilakukan: (1) pengumpulan data, (2) reduksi data, (3) display data, dan (4) kesimpulan. (Hanafi: 2013, p.123)

\section{HASIL PENELITIAN}

Berdasarkan data-data yang dikemukakan dapat dikemukakan beberapa hasil penelitian, diantaranya :
Gaya Kepemimpinan Kepala Sekolah dalam Meningkatkan Kinerja Guru dan Mutu Sekolah, adalah sebagai berikut:

Gaya kepemimpinan yang diterapkan oleh Kepala SD Negeri 02 Batipuh terhadap tenaga pendidik dan tenaga kependidikan adalah gaya demokratis yang lebih banyak menonjol karena Kepala SD Negeri 02 Batipuh memberikan wewenang secara luas kepada para bawahan yaitu para guru dan karyawan. Gaya kepemimpinan yang diterapkan oleh Kepala SD Negeri 02 Batipuh terhadap peserta didik adalah lebih menonjol gaya kepemimpinan yang otoriter, Kepala SD Negeri 02 Batipuh melakukan gaya tersebut tergantung situasi dan kondisi. Gaya kepemimpinan yang diterapkan oleh Kepala SD Negeri 02 Batipuh terhadap tamu dan masyarakat adalah terkesan menggunakan gaya kepemimpinan yang penuh dengan kharismatik.

\section{Strategi Kepemimpinan Kepala Sekolah dalam Meningkatkan Kinerja Guru dan Mutu Sekolah, adalah sebagai berikut:}

Strategi kepemimpinan Kepala SD Negeri 02 Batipuh dalam bentuk pendidikan dan pelatihan (diklat), antara lain seperti berikut ini: (1). In-bouse training (IHT). Pelatihan dalam bentuk IHT adalah pelatihan yang dilaksanakan secara internal di kelompok kerja guru, sekolah atau tempat lain yang ditetapkan untuk menyelenggarakan pelatihan. (2). Kemitraan sekolah, Pelatihan melalui kemitraan sekolah dapat dilaksanakan antara sekolah yang baik dengan yang kurang baik, antara sekolah negeri dengan sekolah swasta, dan sebagainya. (3). Belajar jarak jauh, Pelatihan melalui belajar jarak jauh dapat dilaksanakan 
tanpa menghadirkan instruktur dan peserta pelatihan dalam satu tempat tertentu, melainkan dengan sistem pelatihan melalui internet dan sejenisnya. (4). Pelatihan berjenjang dan pelatihan khusus, dilaksanakan di lembaga-lembaga pelatihan yang diberi wewenang, dimana program disusun secara berjenjang mulai dari jenjang dasar, menengah, lanjut dan tinggi. (5). Kursus singkat di perguruan tinggi atau lembaga pendidikan lainnya, Kursus singkat dimaksudkan untuk melatih meningkatkan kemampuan guru dalam beberapa kemampuan seperti kemampuan melakukan penelitian tindakan kelas, menyusun karya ilmiah, merencanakan, melaksanakan dan mengevaluasi pembelajaran, dan lain-lain sebagainya. (6). Pembinaan internal oleh sekolah, Pembinaan internal ini dilaksanakan oleh Kepala sekolah dan guruguru yang memiliki kewenangan membina, melalui rapat dinas, rotasi tugas mengajar, pemberian tugas-tugas internal tambahan, diskusi dengan rekan sejawat dan sejenisnya. (7). Pendidikan lanjut, Pembinaan profesi guru melalui pendidikan lanjut juga merupakan alternatif bagi peningkatan kualifikasi dan kompetensi guru (8). KKG/MGMP, tujuan yang ingin dicapai dengan adanya revitalisasi kegiatan.

\section{Hasil Kepemimpinan Kepala Sekolah dalam Meningkatkan Kinerja Guru dan Mutu Sekolah, adalah sebagai berikut:}

Peningkatan kedisiplinan guru dan karyawan yang dilakukan Kepala Sekolah adalah dengan menerapkan kedisiplinan melalui: (1) pembinaan, (2) pengawasan dan (3) tindakan dalam disiplin. Kepala SD Negeri 02 Batipuh menyusun peraturan dan mengontrol kedisiplinan siswa sehingga para siswa dapat melaksanakan dengan baik dan juga Peningkatan Kompetensi Peserta di Bidang Penelitian Tindakan Kelas (PTK).

\section{PENUTUP}

\section{Kesimpulan}

Gaya Kepemimpinan Kepala Sekolah dalam Meningkatkan Kinerja Guru dan Mutu Sekolah adalah gaya kepemimpinan yang demokratis yang lebih banyak menonjol karena Kepala SD Negeri 02 Batipuh memberikan wewenang secara luas kepada para bawahan yaitu para guru dan karyawan. Gaya kepemimpinan yang otoriter, yang diterapkan kepada peserta didik. Kepala SD Negeri 02 Batipuh melakukan gaya tersebut tergantung situasi dan kondisi di lapangan. Gaya kepemimpinan yang penuh dengan kharismatik, yang diterapkan terhadap tamu dan masyarakat. Strategi Kepemimpinan Kepala Sekolah dalam Meningkatkan Kinerja Guru dan Mutu Sekolah adalah dengan In-house training (IHT), Kemitraan sekolah, Belajar jarak jauh, Pelatihan berjenjang dan pelatihan khusus, Kursus singkat di perguruan tinggi atau lembaga pendidikan lainnya, Pembinaan internal oleh sekolah, Pendidikan lanjut dan KKG/MGMP. Hasil Kepemimpinan Kepala Sekolah dalam Meningkatkan Kinerja Guru dan Mutu Sekolah adalah dengan meningkatan kedisiplinan guru dan karyawan yang dilakukan Kepala Sekolah adalah dengan menerapkan kedisiplinan melalui: (1) pembinaan, (2) pengawasan dan (3) tindakan dalam disiplin. Kepala SD Negeri 02 Batipuh menyusun peraturan dan mengontrol kedisiplinan siswa sehingga 
para siswa dapat melaksanakan dengan baik.

\section{Saran}

Berikut ini akan dikemukakan beberapa saran yang perlu diperhatikan oleh berbagai pihak, di antaranya :

a. Diharapkan kepada Dinas Pendidikan dan Kementerian Agama Kabupaten Tanah Datar untuk meningkatkan perhatiannya terhadap berbagai Kepemimpinan yang dilakukan oleh Kepala SD Negeri 02 Batipuh dalam meningkatkan efektifitas pembelajaran.

b. Diharapkan kepada Kepala SD Negeri 02 Batipuh untuk meningkatkan komunikasi dan koordinasi dengan Dinas Pendidikan dan Kementerian Agama Kabupaten Tanah Datar, sehingga peningkatan efektifitas pembelajaran dapat dilaksanakan dengan optimal.

c. Diharapkan kepemimpinan Kepala SD Negeri 02 Batipuh untuk dapat menjadi pelayanan dalam pendidikan dan menjadi sentral kekuatan dalam rangka meningkatkan kualitas pendidikan.

d. Diharapkan kepada guru untuk meningkatkan profesionalismenya sehingga dapat melaksanakan tugas dan tanggung jawab sebagai guru secara optimal.

\section{KEPUSTAKAAN ACUAN}

Danim S, Inovasi Pendidikan, 2002, Bandung: CV. Pustaka Setia.
Darji Darmodiharjo, Petunjuk Pelaksanaan tentang Pengembangan sekolab sebagai pusat kebudayaan dan peningkatan ketahanan sekolah, 1982, Jakarta: Balai Pustaka.

Dzaujak Ahmad, Penunjuk Peningkatan Mutu pendidikan di sekolah Dasar, 1996, Jakarta: Depdikbud.

Gomez Meija, D.B. Balkin dan R.L. Cardy, Manajing Human Resources, 2001, USA: Prentice Hall.

Hanafi, Abdul Halim. Metodologi Penelitian Kependidikan, 2013, Batusangkar: STAIN Batusangkar Press.

Hendiyat Soetopo, Wasty Soemanto, Kepemimpinan dan Supervisi Pendidikan, 1988, Jakarta: PT. Bina Aksara.

M. Ngalim Purwanto, Administrasi dan Supervisi Pendidikan, 1991, Bandung: PT. Remaja Rosdakarya.

Oemar Hamalik, Evaluasi Kurikulum, 1990, Bandung: Remaja Rosda Karya

Paul Hersey, Blanchard and H. Kenneth, Management of Organisational behavior: Utilizing Human Resources, 1977, Englewood Cliffs: Prentice-Hall, Inc

Simamora, Manajemen Sumber Daya Manusia, 1995, Yokyakarta: STIE YPKN.

Tabrani Rusyan, dkk. Upaya Meningkatkan Budaya Kinerja Guru, 2000, Cianjur: CV Dinamika Karya Cipta.

Undang-Undang No. 14 tahun 2005 tentang Guru dan Dosen.

Wahjosumidjo, Kepemimpinan Kepala Madrasah Tinjauan Teoritik dan Permasalahan, 1999, Jakarta: Raja Grafindo Persada. 